Canadian

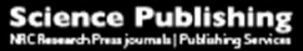

Botany

Botanique

\title{
Morphological, anatomical and ultrastructural changes in Vaccinium corymbosum fruits during ontogeny
}

\begin{tabular}{|r|l|}
\hline Journal: & Botany \\
\hline Manuscript ID: & cjb-2015-0050.R2 \\
\hline Manuscript Type: & Article \\
\hline Date Submitted by the Author: & 16 -Jun-2015 \\
\hline Complete List of Authors: & $\begin{array}{l}\text { Konarska, Agata; University of Life Sciences in Lublin, Department of } \\
\text { Botany }\end{array}$ \\
\hline Keyword: & $\begin{array}{l}\text { highbush blueberry, fruit surface, fruit texture, stone cells and plastids, } \\
\text { tannins and anthocyanins }\end{array}$ \\
\hline \multicolumn{2}{|l}{} \\
\hline
\end{tabular}

SCHOLARONE ${ }^{\text {M }}$

Manuscripts 
Morphological, anatomical and ultrastructural changes in Vaccinium corymbosum fruits during ontogeny

Agata Konarska

Department of Botany, University of Life Sciences in Lublin, Akademicka 15, 20-950 Lublin, Poland

Telephone: +48 8144560 84, e-mail address: agata.konarska@up.lublin.pl 
Abstract. Given their attractive appearance and flavour as well as high antioxidant content, Vaccinium corymbosum L. fruits are greatly appreciated by consumers. These quality traits are primarily dependent on pomological characteristics of the cultivar. 'Bluecrop' is one of the most popular and valuable cultivars of highbush blueberry; however, its fruits become soft shortly after harvesting. Changes in the fruit structure and in the content of phenolic compounds and, in particular, emergence of some traits related to fruit firmness and shelf life, were analysed in the surface layers of 'Bluecrop' fruits from the stage of flowering through the fruit set stage to harvest maturity using light microscopy, transmission electron microscopy, and scanning electron microscopy. The study involved investigations of qualitative and quantitative changes in the development and microstructure of epicuticular wax, cuticle, epidermis, hypodermis, and stone cells and analysis of the presence of tannins and anthocyanins. Moreover, it was found that the development of many traits associated with fruit firmness and shelf life started in the initial period of ontogeny. These results can be useful for the researchers developing new cultivars in detection of early manifestations of developmental features of specific quality traits and in comparative analyses of blueberry cultivars differing in fruit firmness and shelf life.

Keywords: highbush blueberry; fruit surface; fruit texture; stone cells and plastids; tannins and anthocyanins; quality features 


\section{Introduction}

Cultivation of highbush blueberry is a dynamically developing horticultural branch primarily in the warm temperate, sub-tropical, and tropical areas of the world. Blueberries are commercially cultivated and fresh and processed fruits are commonly consumed in North America, Europe, Canada, Australia, New Zealand, China, and Chile (Vaughan and Geissler 1997; Strik 2005; Strik et al. 2014). In general, the production of the fruit involves relatively low levels of fertilisation and chemical protection, hence, highbush blueberry plantations easily receive an ecological farming status, which additionally increases the values of the species (Kęsik and Wach 2010). Moreover, blueberries are referred to as functional food due to the high content of health-promoting substances e.g. flavonoids, tannins, and phenolic acids (Łata and Wińska-Krysiak 2010; Patel 2014; Souza de et al. 2014).

The major objectives of blueberry breeders have focused on horticulturally important traits, such as high productivity and plant vigour, improved disease resistance, uniformly large size, intense colour, flavour, longer fruit storage, and expanded harvest dates (Hancock et al. 2008). Consumers demand high quality fruit, which is dependent on cultivar characteristics as well as postharvest handling. The fruits of different blueberry cultivars and species differ in many qualitative traits, e.g. size, colour, abundance and structure of surface wax (Sapers et al. 1984a, 1984b; Lohachoompol 2007), presence of stone cells (Gough 1983; Blaker and Olmstead 2014), content and composition of phenolic compounds (Castrejón et al. 2008; Kim et al. 2013), particularly anthocyanins (Burdulis et al. 2009; Su 2012), or the size of the picking scar (Pliszka 2002; Parra et al. 2007). Many of these traits have an impact on the firmness and shelf life of mature fruits (Hancock et al. 2008), which is also largely dependent on characteristics related to the texture of i) the epidermis, i.e. the cell size and shape, arrangement, thickness of walls, and distribution and bleeding of the pigment; ii) the subepidermal area as a transition layer, i.e. the degree of cell-to-cell contact and amount of air 
spaces; and iii) the flesh, i.e. cell-to-cell contact, cell wall integrity, and presence of interfaces with parenchyma cells (Toivonen and Brummell 2008; Chiabrando et al. 2009; Matiacevich et al. 2013).

The false berries of the highbush blueberry represent the so-called "soft fruits" (Suzuki et al. 1997; Perkins-Veazie 2004) and they are characterised by a double-sigmoid growth pattern (Godoy et al. 2008; Jorquera-Fontena et al. 2014). Some quality traits related to the microstructure of $V$. corymbosum fruits have been previously presented by other researchers (Bünemann et al. 1957; Gough 1983; Sapers et al. 1984a; Alan-Wojtas et al. 2001; Lohachoompol 2007; Blaker and Olmstead 2014). Their research was carried out only on mature fruits and was related to the location of pigments, structure of cuticle and epicuticular waxes, texture of skin and flesh, as well as presence of stone cells. In the available literature there is no information about the course of development of the qualitative traits associated with the microstructure in immature fruits. The sites of synthesis and modes of transport of tannins, wax, and cuticular components at the cellular level are unknown. At different stages of fruit development, the microstructure of fruits can provide important information about the changes that take place in the contribution of individual tissues forming the fruit and provide a better understanding of the physiological mechanisms and processes occurring in the developing fruit.

This study involves the 'Bluecrop' cultivar, one of the most valuable cultivars that is characterised by high fertility, attractive fruits, and high levels of antioxidants and recommended for commercial and amateur cultivation (Żurawicz 2003; Strik et al. 2014). The aim of the study was to determine changes in the micromorphology, histology, and, for the first time, in the ultrastructure of the surface layers in 'Bluecrop' fruits occurring from the flowering time through initial growth until full harvest maturity. Particular attention was 
devoted to the development of some qualitative traits associated with fruit firmness, shelf life, and the content of phenolic compounds.

\section{Material and Methods}

The investigations were carried out in 2014 on a private plantation of the highbush blueberry (Vaccinium corymbosum L.) in Spiczyn near Lublin, Poland $\left(22^{\circ} 46^{\prime} \mathrm{E}\right.$ and $51^{\circ}$ $21^{\prime} \mathrm{N}$ ), in an area characterised by a temperate continental climate. The plantation was established in the autumn of 2010. The bushes grew at $3.3 \times 1 \mathrm{~m}$ spacing on sawdust mulch under a drip irrigation system. The conventional cultivation method was used involving application of standard mineral fertilisers and chemical plant protection products and a substrate with $\mathrm{pH}$ ca. 4.0 (using $1 \mathrm{n} \mathrm{KCl}$ ). The fruits of the 'Bluecrop' cultivar were analysed in 3 developmental stages: stage I - anthesis stage (May 15, at day 4 after flower opening and corolla and stamens falling off), stage II - fruit set stage (June 20, 35 days after anthesis), and stage III - fruit harvest maturity stage (July 25, 70 days after anthesis). Withering flowers as well as fruits in stage II and III characterised by similar colour and size were collected from the central part of randomly chosen bushes. While picking, transporting, and preparing the berries for SEM, special care was taken so as not to touch the fruit surface that was intended for observation (to avoid rubbing off and degradation of the wax layer). A stereoscopic microscope (SLM) SMT 800 coupled with a NIKON COOLPIX 4500 camera was used for measurements of the width (at half height) and the height of 20 hypanthia, 20 immature fruits, and 20 mature fruits. Additionally, the location of stomata on their surface was determined and the size of the picking scar was measured in stage II and III. Next, for microscopic analysis, hypanthium and fruit fragments with skin were sampled from the equatorial part of the examined organs.

Scanning electron microscopy (SEM) 
Conventional fixation of material used for SEM observations involves dehydration, which can alter or remove lipids that form the wax coating on the berry surface, and critical point drying, which can distort and shrink tissues (Roy et al. 1999). Therefore, 5 whole hypanthia and 5 samples of the external part of the immature fruits and mature fruits $(5 \mathrm{~mm} x$ $5 \mathrm{~mm} \times 2 \mathrm{~mm}$ ) were mounted carefully onto aluminium stubs with a double-sided carbon tape, immediately after the fruits had been collected from the plants. No drying was applied to the samples (Konarska 2013a, 2013b). When coated with a 15-nm thick layer of gold, the samples were examined under a TESCAN/VEGA LMU scanning electron microscope at an accelerating voltage of $10 \mathrm{kV}$.

\section{Light microscopy (LM)}

Semi-thin $0.7-\mu \mathrm{m}$ transverse sections (perpendicular to the fruit axis) through 10 hypanthia with skin and 10 immature fruits and mature fruits with skin (stages II and III) of the 'Bluecrop' were cut using a Reichert Ultracut-S ultramicrotome and a glass knife. Next, the sections were stained with $1 \%$ methylene blue and $1 \%$ azure II in a $1 \%$ aqueous solution of sodium tetraborate. The samples were fixed and embedded in synthetic resin with the standard transmission electron microscopy method (see the paragraph below). The measurements (5 from each slide) comprised the thickness of epicuticular waxes and the cuticle, the thickness of the outer epidermal cells, the height and width of the epidermal cells, the thickness of the hypodermis layer, the thickness of the hypodermal cell walls (measured at half width of the cells), the total skin thickness (epidermis plus hypodermis), the length of plastids in hypodermis cells, the thickness of stone cell walls, as well as the height (measured along the radial axis) and number of stone cells located in the surface layer $(0-0.5 \mathrm{~mm})$ of fruits in stage II and III. The sections were observed under a Nikon Eclipse 90i microscope and the images were obtained using a digital camera (Nikon Fi1) and NIS-Elements Br 2 software. Additionally, using a razor blade, hand-cut cross-sections were made through 5 
'Bluecrop' fresh hypanthia with skin (stage I) and 5 fresh fruits with skin (stages II and III). Next, the samples were stained with Sudan III (a saturated ethanolic solution of Sudan III) to visualize lipophilic substances, Lugol's iodine (IKI) to detect starch, as well as with potassium dichromate and ferric chloride to detect tannins and polyphenol compounds, respectively. The preparations were examined under a Nikon SE 102 light microscope.

Transmission electron microscopy (TEM)

Small samples (ca. $2 \mathrm{~mm} \times 2 \mathrm{~mm} \times 2 \mathrm{~mm}$ ) of 5 hypanthia (stage I) and fruits in stages II and III were fixed in 2\% paraformaldehyde and 2.5\% glutaraldehyde buffered at pH 7.4 in $0.1 \mathrm{M}$ cacodylate buffer. Fixation was performed at room temperature for two hours, followed by $12 \mathrm{~h}$ at $4^{\circ} \mathrm{C}$. When fixed, the samples were rinsed with $0.1 \mathrm{M}$ cacodylate buffer at $4^{\circ} \mathrm{C}$ for $24 \mathrm{~h}$ and then treated with $1 \% \mathrm{OsO}_{4}$. Subsequently, the samples were transferred to redistilled water and stained with a $0.5 \mathrm{M}$ aqueous solution of uranyl acetate. After passage through increasing concentrations of propylene oxide in ethanol and finally through pure propylene oxide, the samples were embedded for $12 \mathrm{~h}$ in Spurr Low Viscosity resin at $70^{\circ} \mathrm{C}$ (Spurr 1969). Ultrathin sections (70 nm thick) were treated with a $8 \%$ solution of uranyl acetate in acetic acid and with lead citrate (Reynolds 1963). Samples were observed using the FEI Technai G2 Spirit Bio TWIN transmission electron microscope at an accelerating voltage of $120 \mathrm{kV}$. Images were captured using a Megaview G2 Olympus Soft Imaging Solutions camera.

Statistical analyses

Means and standard deviations $( \pm \mathrm{SD})$ were calculated for all the measured parameters using Excel 7.0 software (Microsoft, Redmond, Wash). Data were analysed by one-way analysis of variance (ANOVA) and Tukey's HSD test for comparison of means, using software STATISTICA 7.0 (StatSoft, Inc., USA). Differences were considered statistically significant at the level of $\alpha=0.05$. 


\section{Results}

Anthesis (stage I)

The hypantia in the 'Bluecrop' flowers had a height of ca. $1.6 \mathrm{~mm}$ and were wider by $60 \%$ (Fig. 1a, b). The surface of the hypantia was formed by a single-layered epidermis composed of cells with a rectangular outline and comprising stomata, which were particularly numerous near and on the sepals but absent in the equatorial plane and in the pedicel zone of the hypanthium (Fig. 1c-e). The epidermis surface exhibited crystalline wax in the form of rods and rodlets, which in some sites were relatively densely arranged, whereas in other sites the cuticle surface was smooth with no coating (Fig. 1e-h). The thin-walled epidermal cells had a height which was significantly greater (by ca. 75\%) than the width; they were covered by a thin layer of an amorphous cuticle and a layer of crystalline wax that was greater than half the thickness $(42 \%)$ of the cuticle (Table 1; Figs 1i, j; 2a). Under the epidermis, there were two layers of hypodermal cells that were more rectangular than oval and had thin periclinal walls. Underneath the hypodermal layers, there was parenchyma composed of different size oval cells with scattered vascular bundles (Table 1; Fig. 2a-c). The parenchymal and hypodermal cells contained numerous plastids (Fig. 2b-c). In many chloroplasts, tiny, almost black, oval structures, possibly deposits of tannins, were visible (Fig. 2b). In turn, all layers of cells forming the hypanthium wall exhibited tannin deposits, which were stained brown with potassium dichromate. The deposits located in the vacuoles had oval shapes and varied sizes (Fig. 2a, b, d). No stone cells and no starch grains were noted in the hypanthium cells at this stage of development.

\section{Immature fruits (stage II)}

35-day-old 'Bluecrop' immature fruit were ca. 4-fold wider and higher than in stage I, and the diameter of the picking scar did not exceed $2 \mathrm{~mm}$ (Table 1; Fig. 3a, b). As in stage I, 
the stomata on the surface of the immature fruits were only found near the calyx region. The surface of the fruit sets was covered by wax coating formed by densely arranged rods and rodlets, whose layer was 2-fold thicker than in the anthesis stage (Table 1; Fig. 3c-f). Between areas covered abundantly by wax crystals, only amorphous wax formed from numerous fused crystals was visible (Fig. 3d). This variation of the epicuticular wax structure was also observed in SLM, which showed a specific mosaic of lighter (crystalline wax) and darker (crystalline wax) patches on the grey-green surface of the stage II fruits (Fig. 3b). In TEM, small, electron-dense granularities were visible in the crystalline wax layer (Fig. $3 f, g$ ). The cuticle visible under the wax layer exhibited clear orange staining when treated with Sudan III; it was over 2.5-fold thicker than during the anthesis stage (Table 1; Fig. 3e, f, h) and exhibited a distinct darker cuticular layer and a lighter cuticle proper which is the outer layer of cuticle composed primarily of cutin embedded in intracuticular waxes (Fig. 3f, h). Similarly, the epidermal outer cell walls were also ca. 2.5 -fold thicker than in stage I; they usually contained oval, electron-dense structures (inclusions), which were especially numerous at the junction of the periclinal and anticlinal walls and at the border of the periclinal wall and the cuticle (Fig. 3e, f, h, i). The epidermis was formed of one layer of cells that were nearly square in outline and were higher (by 43\%) and 1.5 fold wider than in the anthesis stage (Table 1; Figs 3e; 4a-c). Under the epidermis, there was a usually doublelayered hypodermis, which was36\% thicker than in stage I; it was composed of cells that were flattened along the perimeter and had 3-fold thicker periclinal walls than in the anthesis stage (Table 1; Fig. 4a, b). In LM, the vacuoles of viable epidermal and hypodermal protoplasts contained oval, different sized deposits of condensed tannins staining brown with potassium dichromate (Fig. 4c). Different shape and size stone cells were mainly observed in the peripheral parenchyma layers, but rarely in the pericarp hypodermis (Table 1; Fig. 4a). Unfixed sclereids exhibited dense cytoplasm and large vacuoles, and their secondary lignified 
cell walls stained orange with Sudan III (not shown). In turn, hypodermis and parenchyma cells contained numerous plastids of similar size to that in the anthesis stage (Table 1; Fig. 4dh). Besides typical, lens-shaped chloroplasts containing thylakoids and osmiophilic globules (Fig. 4d), there were oval plastids that either were characterised by distorted thylakoid arrangement or were devoid of thylakoids and contained numerous electron-transparent structures (Fig. 4e-g), as well as longer plastids (approx. $9 \mu \mathrm{m}$ ) surrounded by electrontransparent vesicles, probably liberated from the interior of the plastids (Fig. 4h). No starch grains were observed in any of the types of plastids.

\section{Mature fruits (stage III)}

At day 70 after the anthesis, the diameter of the picking scar in mature 'Bluecrop' fruits was by over $30 \%$ greater, and the fruits reached were over 1.5 -fold wider and 2-fold longer than those in the fruit set stage. They were also nearly 7-fold wider and 8-fold longer than in the anthesis stage (Table 1). Moreover, epidermis cracking was visible around the picking scar (not shown). The surface of mature fruits was covered by abundant crystalline wax coating, which was $45 \%$ thicker than that in the fruit set stage but had a similar structure (Table 1; Fig. 5a, b). However, areas covered by a smooth, amorphous wax layer formed by merging crystals were observed more frequently than in stage II (Fig. 5a). In turn, the cuticle was characterised by a reticulate structure visible in TEM and had varied thickness, which was on average 2-fold greater than in the stage II fruits (Table 1; Fig. 5c, d). The epidermis was composed of cells with a more rounded shape than that in the immature fruits and was by ca. $25 \%$ wider and $25 \%$ thicker than those in the immature fruits; in contrast, the height of the outer cell wall was similar (Table 1; Fig. 5e, f). The double-layered hypodermis with a slightly greater thickness than that in stage II was composed of cells that had similarly thickened periclinal walls but were more loosely associated (Table 1; Fig. 5e, f). The epidermis and the hypodermis formed the skin, which was slightly thicker than that in stage II 
and was detached from the fruit parenchyma in many sites (Fig. 5e). In the epidermal cell vacuoles, anthocyanins were visible in the form of large, spherical globules in the living protoplasts (not shown) or granularities in the fixed cells (Fig. 5e, f). Aluminium chloride gave brown staining to the phenolic compounds present in the epicarp of the mature 'Bluecrop' fruits. In turn, the cytoplasm of the epidermal cells contained small, often rounded chloroplasts that were ca. $25-33 \%$ shorter than in the earlier stages and had lost all organization and internal membrane structure (Fig. 6a-e). In their interior, there were chaotically arranged tubules formed of membranes, rarely in the form of ordered lamellae and plastoglobules, or electron-dense granular inclusions of different sizes and shapes (Fig. 6a-c). Some of these granular structures were concentrated outside the plastid envelope as if they had been detached (Fig. 6d-f). The number of sclereids present in the hypodermis and in the adjacent parenchyma layers was similar to that noted in the fruit set stage (Table 1). With depth, the number of stone cells decreased. The size of the stone cells and the thickness of their cell walls were similar to those of the sclereids observed in stage II (Table 1).

\section{Discussion}

Many traits related to the quality of 'Bluecrop' fruits, especially those responsible for their firmness and shelf life, were observed in the morphology, anatomy, and ultrastructure of the surface layers of these organs already at the end of the flower life span. Enlargement of the fruit was accompanied by an increase in the size and changes in the shape of cells, in particular a progressive increase in the thickness of the epicuticular wax layer and the cuticle and in the thickness of the epidermis and hypodermis walls, a process occurring between flowering to fruit ripening. Since these features are associated with the peripheral layers of the fruits, their most important role is to provide protection to the growing pericarp against adverse external bio- and abiotic factors as well as water loss and withering. Many qualitative 
traits have a genetic background, but they also depend on environmental conditions and the degree of maturity at harvest (Connor et al. 2002; Jaakola et al. 2002; Matiacevich et al. 2013).

The presence of the abundant wax coating on the 'Bluecrop' fruits ensures the maintenance of fruit colour, which is preferred by consumers, and limits transpiration. During the ripening period, the amount of the coating increased and so did the fruit surface covered by amorphous wax formed by merging crystals. A similarly diverse wax structure depending on the fruit development stage was observed in different Vaccinium species by other authors, who described areas with deformed wax crystals, that were fused in mature fruits, forming annealed patches (Albrigo et al. 1980; Sapers et al. 1984b; Lohachoompol 2007). According to Wettstein-Knowles von (1995), the type of wax is related to its composition, and wax metabolism is controlled by multiple genes.

The cuticle is another protective layer on the surface of 'Bluecrop' epidermis that has an impact on fruit transpiration. During fruit development, the thickness of the cuticle increased and its structure changed due to the inflow of electron-dense inclusions from the epidermis, which probably contained components of the cuticle and/or waxes. As reported by Peng and Zhang (2000) and Samuels et al. (2008), the synthesis of cuticle components takes place in the endoplasmic reticulum and epidermis chloroplasts and these compounds then have to be transported across the plasmalemma and cell wall to their destination. Other authors also observed an increase in the thickness of the cuticle during fruit development in different Vaccinium species (Özgen et al. 2002; Lohachoompol 2007) and different cultivars of grapes, apples, and pears (Casado and Heredia 2001; Konarska 2013a, 2013b; 2014); in contrast, reduction of cuticle thickness was reported in cherries and plums during fruit development (Knoche et al. 2004; Knoche i Peschel 2007). The amorphous character of the cuticle in the initial stage of 'Bluecrop' fruit development implies involvement of only cutin 
and cutan in its structure, whereas the development of the reticulate cuticle in the stage II fruits and mature fruits indicates appearance of polysaccharide microfibres in its composition. Such relationships between the composition and structure of the cuticle and its properties in different stages of fruit development are reported by Jeffree (2006). Martin and Juniper (1970) and Peschel et al. (2003) claim that the evaporation of water can take place through cuticle microchannels or micropores; similarly, water can also move from the environment to plant cells through these microchannels. Chamel et al. (1991) suggest that the role of the hydrophilic polysaccharides is binding of water. As reported by Kerstiens (1994), the reticulate cuticle is the most permeable, whereas the lamellate structure of the cuticle proper limits transpiration. Additionally, Domínguez et al. (2011) and España et al. (2014) report that cuticle composed mostly of cutin is highly elastic, while greater numbers of polysaccharide fibres contribute to the viscoelastic behaviour of the cuticle. Thus, not only the thickness of the cuticle, but also its composition and structure affect the intensity of transpiration, resulting in a decrease in cell turgor, fruit softening, as well as shortening of the shelf life. De Bellie et al. (2000) also argue that migration and water loss from the vacuoles change the shape and resiliency of cells that are separated from each other, which contributes to a decrease in fruit firmness. Differences in the composition of the cuticle of various fruits were also observed between different species and cultivars (Kallio et al. 2006; Tsubaki et al. 2012), between developmental stages (Peschel et al. 2007; Dong et al. 2012), and among fruits of a single plant, or even spatially across the surface of a single fruit (Maguire et al. 1999; Léchaudel et al. 2013).

We found that the surface of the 'Bluecrop' fruits was devoid of deep microcracks and contained a small number of stomata that were located primarily near the fruit calyx; both these traits also limit fruit transpiration. According to many researchers, the presence of microcracks and open stomata are the main factors promoting water loss, e.g. in apples 
(Konarska 2013a; 2014), grapes (Becker and Knoche 2012), nectarines (Gilbert et al. 2007), pears (Konarska 2013b) and plums (Knoche and Peschel 2007). Similar location of stomata on fruits as well as their low number or absence in other Vaccinium species was also observed by other authors (Özgen et al. 2002; Lohachoompol 2007).

During the development of the 'Bluecrop' fruits, an increase in the diameter of the picking scar was noted; in mature fruits, after detachment of the fruit from the pedicel, cracks appeared around the picking scar, which may contribute to water loss and entry of pathogens into the interior of the fruit. Strik et al. (2014) suggest that for commercial conditions the picking scar is an important horticultural trait for weight loss and decay control. Consumers prefer large fruits with small scars (Galletta and Ballington 1996), whereas there is a tendency in a majority of cultivars to produce larger and heavier fruits with a bigger picking scar (Parra et a. 2007). As reported by Pliszka (2002) and Strik et al. (2014), compared with other cultivars, the picking scar in 'Bluecrop' is relatively small and dry; however, the fruits of this variety fall off after ripening relatively easily due to rapid formation of the cork abscission layer.

The increase in the thickness of the epidermis and hypodermis cell walls observed during the 'Bluecrop' fruit development is another feature of the skin that has a positive impact on fruit firmness. In the skin of immature fruits, the thick-walled cells and close cellto-cell contact are conducive to the maintenance of fruit toughness. On the contrary, the skin cells in mature fruits were more rounded than in stage II fruits, which contributed to the loose packing of cells resulting in large intercellular spaces between groups of cells. A similarly negative effect on the firmness of mature 'Bluecrop' fruits was exerted by dissolution of middle lamellae between the skin and parenchyma causing detachment of the skin from deeper pericarp layers. Many authors believe that fruit firmness is associated with thickness of cell walls, the degree of cell-to-cell contact (packing or density of cells), amount of air spaces, 
and architectural alterations occurring during fruit development and ripening (Allan-Wojtas et al. 2001; Chiabrando et al. 2009; Klima Johnson et al. 2011). Other authors report that cellulose depolymerisation and arabinose loss occurring in the cell wall during fruit ripening are major processes leading to fruit softening (Angeletti et al. 2010; Paniagua et al. 2013). According to many authors, the junctions between cells and cell wall strength have a significant effect on not only fruit firmness but also their crispness, mealiness, gumminess, and juiciness, i.e. factors in determining their economic success (Vicente et al. 2007; Toivonen and Brummell 2008).

The presence of sclereids in the peripheral layer of the 'Bluecrop' stage II fruits and ripe fruits is crucial in determiningthe toughness and shelf life of fruits after harvest. Stone cells with highly thickened, lignified cell walls were surrounded by parenchyma cells with thin, cellulose walls forming so-called stone cell "rosettes". Tian et al. (2011) claims that, since lignin ensures strength, rigidity and impermeability, the stone cells are specific enhancements, i.e. "strong points" maintaining fruit hardness and firmness. Their number and size were constant from at least the middle of the 'Bluecrop' fruit development period. Similar results were presented by Gough (1983), who found that brachysclereids were located mainly in the periphery of the fruit and emerged from ground parenchyma shortly after anthesis. The essential role of stone cells in the maintenance of skin toughness and their impact on fruit texture and prolongation of postharvest life as well as their potential value for mechanical harvesting for fresh market were reported for the first time by Smith (1935) and Sterling (1954) in pear fruits.

The author of the present paper detected two types of phenolic compounds in the 'Bluecrop' fruits: tannins (proanthocyanidins) and anthocyanins. The concentration of the proanthocyanidin deposits was found to be the highest in the flower hypanthia and stage II fruits, but declined slightly during fruit ripening. Similar results showing a decline in the 
tannin content in ripe fruits of various Vaccinium species were obtained by other authors (Lohachoompol 2007; Kalt et al. 2008; Forney et al. 2012). It is believed that proanthocyanidins in unripe fruit provide protection against fungal pathogens and premature feeding by insects, act as anti-pathogenic and anti-herbivoric substances, and are responsible for the characteristic fruit bitterness and astringency (Tessmer et al. 2014; He et al. 2015). In the pericarp cells of the 'Bluecrop' fruits sets, spherical tannin deposits were observed in the vacuoles. Plastids, which contained numerous small vesicles in their interior and outside the envelope, may have been involved in tannin synthesis. The investigations conducted by Wang et al. (2010) and Brillouet et al. (2013) showed that special chloroplast-derived organelles were involved in the polymerisation of tannins; initially, they accumulated tannin molecules in the form of tannosomes and then transported them into the vacuole in characteristic shuttles. Proanthocyanidin deposits in vacuoles were also observed by other authors in fruits of various taxa (Hammouda et al. 2014; Konarska 2014; Tessmer et al. 2014). In turn, the presence of oval chloroplasts with a degenerating thylakoid system and numerous plastoglobules in mature 'Bluecrop' fruits is one of the indicators of fruit ripening and senescence. Such plastids were also found in ripening fruits of other species (Montefiori et al. 2009; Fu et al. 2012).

Like proanthocyanidins, anthocyanins occurring in the form of spherical globoids and providing ripe 'Bluecrop' fruits with the dark blue colour were located in the vacuoles of skin cells. According to many authors, different blueberry varieties differ in the content of anthocyanins (Müller et al. 2012; Scalzo de 2013); the synthesis of these flavonoids is initiated after fruit growth ceases and has the greatest rate during fruit ripening (Lohachoompol 2007; Forney et al. 2012). As reported by Gao and Mazza (1994), as many as 15 different anthocyanins responsible for health-promoting properties have been identified in the skin of ripe Vaccinium corymbosum fruits. 
Many of the structural traits examined in this study, which are associated with the quality of the 'Bluecrop' highbush blueberry fruits, appear at the beginning of the fruit development period. They are mainly related to the peripheral layers in the fruits and determine their firmness and shelf life. During ripening, fruit firmness and fruit texture in blueberries undergo the greatest changes, leading to substantial losses in the quality during shelf life and storage. Investigations of the microstructure of blueberry fruit contribute to a better understanding of the mechanisms and processes that take place during their development, and can help identify positive and or negative attributes associated with the quality of the fruit. These results may be useful for researchers developing new cultivars to detect early manifestations of developmental features of specific qualitative traits and in comparative analyses of blueberry cultivars differing in fruit firmness and shelf life. In addition, microstructural investigations can complement the sensory, chemical, and instrumental methods for examining the qualitative traits of fruits and can provide new insight into the quality of blueberry fruits. Furthermore, the unique examinations of the ultrastructure of the fruit skin provide new information about the diverse role and structure of plastids and synthesis of the epicuticular wax and cuticle components.

\section{Acknowledgments}

This work was supported by the Ministry of Science and Higher Education of Poland as part of the statutory activities of the Department of Botany, University of Life Sciences in Lublin.

\section{References}

Albrigo, L.G., Lyrene, P.M., Freeman, B. 1980. Waxes and other characteristics of fruit and leaves of native Vaccinium elliotti Chapm. J. Am. Soc. Hortic. Sci. 105(2): 230-235. 
Angeletti, P., Castagnasso, H., Miceli, E., Terminiello, L., Concellon, A., Chaves, A., Vicente, A.R. 2010. Effect of preharvest calcium applications on postharvest quality, softening and cell wall degradation of two blueberry (Vaccinium corymbosum) varieties. Postharvest $\quad$ Biol. $\quad$ Technol. 58: 98-103. doi:10.1016/j.postharvbio.2010.05.015.

Becker, T., Knoche, M. 2012. Deposition, strain, and microcracking of the cuticle in developing 'Riesling' grape berries. Vitis 51(1): 1-6.

Blaker, K.M., Olmstead, J.W. 2014. Stone cell frequency and cell area variation of crisp and standard texture southern highbush blueberry fruit. J. Am. Soc. Hortic. Sci. 139(5): $553-557$.

Brillouet, J.M., Romieu C., Schoefs, B., Solymosi, K., Cheynier, V., Fulcrand, H., ... \& Conéjéro, G. 2013. The tannosome is an organelle forming condensed tannins in the chlorophyllous organs of Tracheophyta. Ann. Bot. 112: 1003-1014. doi:10.1093/aob/mct168.

Burdulis, D., Sarkinas, A., Jasutiené, I., Stackevicené, E., Nikolajevas, L., Janulis, V. 2009. Comparative study of anthocyanin composition, antimicrobial and antioxidant activity in bilberry (Vaccinium myrtillus L.) and blueberry (Vaccinium corymbosum L.) fruits. Acta Pol. Pharm. 66(4): 399-408.

Casado, C.G., Heredia, A. 2001. Ultrastructure of the cuticle during growth of the grape berry (Vitis vinifera). Physiol. Plant. 111: 220-224. doi:10.1034/j.13993054.2001.1110213.x.

Castrejón, A.D.R., Eichholz, I., Rohn, S., Kroh, L.W., Huyskens-Keil, S. 2008. Phenolic profile and antioxidant activity of highbush blueberry (Vaccinium corymbosum L.) during fruit maturation and ripening. Food Chem. 109(3): 564-72. doi:10.1016/j.foodchem.2008.01.007. 
Chamel, A., Pineri, M., Escouhes, M. 1991. Quantitative determination of water sorption by plant cuticles. Plant Cell Environ. 14: 87-95. doi:10.1111/j.1365-3040.1991.tb01374.x.

Chiabrando, V., Giacalone, G., Rolle, L. 2009. Mechanical behaviour and quality traits of highbush blueberry during postharvest storage. J. Sci. Food Agric. 89: 989-992. doi:10.1002/jsfa.3544.

Connor, A.M., Luby, J.J., Tong, C.B.S., Finn, C.E., Hancock, J.F. 2002. Genotypic and environmental variation in antioxidant activity, total phenolics and anthocyanin content among blueberry cultivars. J. Am. Soc. Hortic. Sci. 127: 89-97.

De Belie, N., Hallett, I.C., Harker, F.R., De Baerdemaeker, J. 2000. Influence of ripening and turgor on the tensile properties of pears: A microscopic study of cellular and tissue changes. J. Am. Soc. Hortic. Sci. 125(3): 350-356.

Domínguez, E., Cuartero, J., Heredia, A. 2011. An overview on plant cuticle biomechanics. Plant Sci. 181(2): 77-84. doi:10.1016/j.plantsci.2011.04.016.

Dong, X., Rao, J., Huber, D.J., Chang, X., Xin, F. 2012. Wax composition of 'Red Fuji' apple fruit during development and during storage after 1-methylcyclopropene treatment. Hortic. Environ. Biotechnol. 53: 288-297. doi:10.1007/s13580-012-0036-0.

España, L., Heredia-Guerrero, J.A., Segado, P., Benítez, J.J., Heredia, A., Domínguez, E. 2014. Biomechanical properties of the tomato (Solanum lycopersicum) fruit cuticle during development are modulated by changes in the relative amounts of its components. New Phytol. 202(3): 790-802. doi:10.1111/nph.12727.

Forney, C.F., Kalt, W., Jordan, M.A., Vinqvist-Tymchuk, M.R., Fillmore, S.A. 2012. Blueberry and cranberry fruit composition during development. J. Berry Res. 2(3): $169-177$. 
Fu, X., Kong, W., Peng, G., Zhou, J., Azam, M., Xu, C.,... \& Chen, K. 2012. Plastid structure and carotenogenic gene expression in red-and white-fleshed loquat (Eriobotrya japonica) fruits. J. Exp. Bot. 63(1): 341-354. doi: 10.1093/jxb/err284.

Galletta, G.J., Ballington, J.R. 1996. Blueberries, cranberries and lingonberries. In Fruits breeding. 2, Vine and small fruits crops. Edited by J. Janick, Moore J.N. Prentice Hall, New York. pp. 1-107.

Gao, L., Mazza, G. 1994. Quantitation and distribution of simple and acylated anthocyanins and other phenolics in blueberries. J. Food Sci. 59(5): 1057-59. doi:10.1111/j.13652621.1994.tb08189.x.

Gibert, C., Chadoeuf, J., Vercambre, G., Génard, M., Lescourret, F. 2007. Cuticular cracking on nectarine fruit surface: spatial distribution and development in relation to irrigation and thinning. J. Am. Soc. Hortic. Sci. 132(5): 583-591.

Godoy, C., Monterubbianesi, G., Tognetti, J. 2008 Analysis of highbush blueberry (Vaccinium corymbosum L.) fruit growth with exponential mixed models. Sci. Hort. 115: 368-376. doi:10.1016/j.scienta.2007.10.018.

Gough, R.E. 1983. The occurrence of mesocarpic stone cells in the fruit of cultivated highbush blueberry. J. Am. Soc. Hortic. Sci. 108: 1064-1067.

Hammouda, H., Alvarado, C., Bouchet, B., Kalthoum-Chérif, J., Trabelsi-Ayadi, M., Guyot, S. 2014. Tissue and cellular localization of tannins in tunisian dates (Phoenix dactylifera L.) by light and transmission electron microscopy. J. Agric. Food Chem. 62(28): 6650-6654. doi:10.1021/jf5013715.

Hancock, J.F., Lyrene, P., Finn, C.E., Vorsa, N., Lobos, G.A. 2008. Blueberries and cranberries. In Temperate fruit crop breeding. Edited by J.F. Hancock. Springer, New York. pp 115-149. 
He, M., Tian, H., Luo, X., Qi, X., Chen, X. 2015. Molecular progress in research on fruit astringency. Molecules 20(1): 1434-1451. doi:10.3390/molecules20011434.

Jaakola, L., Määttä, K., Pirttilä, A.M., Törrönen, R., Kärenlampi, S., Hohtola, A. 2002. Expression of genes involved in anthocyanin biosynthesis in relation to anthocyanin, proanthocyanidin, and flavonol levels during bilberry fruit development. Plant Physiol. 130(2): 729-739. doi.org/10.1104/pp.006957.

Jeffree, C.E., 2006. The fine structure of the plant cuticle. In Biology of the plant cuticle. Edited by M. Riederer, C. Müller. Blackwell Publishing, Oxford. pp 11-125.

Jorquera-Fontena, E., Alberdi, M., Franck, N. 2014. Pruning severity affects yield, fruit load and fruit and leaf traits of 'Brigitta' blueberry. J. Soil Sci. Plant Nutr. 14(4): 855-868. doi:10.4067/S0718-95162014005000068.

Kallio, H., Nieminen, R., Tuomasjukka, S., Hakala, M. 2006. Cutin composition of five finnish berries. J. Agric. Food Chem. 54(2): 457-462. doi:10.1021/jf0522659.

Kalt, W., MacKinnon, S., McDonald, J., Vinqvist, M., Craft, C., Howell, A. 2008. Phenolics of Vaccinium berries and other fruit crops. J. Sci. Food Agric. 88(1): 68-76. doi:10.1002/jsfa.2991.

Kerstiens, G. 1994. Air pollutants and plant cuticles: mechanisms of gas and water transport, and effects on water permeability. In: Air pollutants and the leaf cuticle. Edited by K.E. Percy, J.N. Cape, R. Jagels, C.J. Simpson. Springer, Berlin. pp 39-52.

Kęsik, T., Wach, D. 2010. Estimation of growth and yielding of highbush blueberry (Vacinium corymbosum L.) cultivated on a soil developed from loamy sand. Zeszyty Problemowe Postępów Rolniczych 556: 711-716.

Kim, J.G., Kim, H.L., Kim, S.J., Park, K.S. 2013. Fruit quality, anthocyanin and total phenolic contents, and antioxidant activities of 45 blueberry cultivars grown in Suwon, Korea. J. Zhejiang Univ. 14(9): 793-799. doi: 10.1631/jzus.B1300012. 
Klima Johnson, L., Malladi, A., Scott NeSmith, D. 2011. Differences in cell number facilitate fruit size variation in Rabbiteye blueberry genotypes. J. Am. Soc. Hortic. Sci. 136: 1015.

Knoche, M., Beyer, M., Peschel, S., Oparlakov, B., Bukovac, M.J. 2004. Changes in strain and deposition of cuticle in developing sweet cherry fruit. Physiol. Plant. 120: 667677. doi:10.1111/j.0031-9317.2004.0285.x.

Knoche, M., Peschel, S. 2007. Deposition and strain of the cuticle of developing European plum fruit. J. Am. Soc. Hortic. Sci. 132(5): 597-602.

Konarska, A. 2013a. The structure of the fruit peel in two varieties of Malus domestica Borkh. (Rosaceae) before and after storage. Protoplasma 250: 701-714. doi:10.1007/s00709012-0454-y.

Konarska, A. 2013b. The relationship between the morphology and structure and the quality of fruits of two pear cultivars (Pyrus communis L.) during their development and maturation [online]. Sci.WorldJ. 2013: 13 pages. doi.org/10.1155/2013/846796.

Konarska, A. 2014. Morphological, histological and ultrastructural changes in fruit epidermis of apple Malus domestica cv. Ligol (Rosaceae) at fruit set, maturity and storage. Acta Biol. Cracov. Bot. 56(2): 35-48. doi:10.2478/abcsb-2014-0019.

Léchaudel, M., Lopez-Lauri, F., Vidal, V., Sallanon, H., Joas, J. 2013. Response of the physiological parameters of mango fruit (transpiration, water relations and antioxidant system) to its light and temperature environment. J. Plant Physiol. 170: 567-576. doi:10.1016/j.jplph.2012.11.009.

Lohachoompol, V. 2007. Effects of drying on anthocyanins in blueberries. PhD thesis, The University of New South Wales, Sydney, Austrlia. 
Łata, B., Wińska-Krysiak, M. 2010. Cultivar and seasonal variation in bioactive compounds of highbush blueberry fruits (Vaccinium corymbosum L.). Folia Hort. 22(1): 31-35. doi: 10.2478/fhort-2013-0148.

Maguire, K.M., Banks, N.H., Lang, A. 1999. Sources of variation in water vapour permeance of apple fruit. Postharvest Biol. Technol. 17: 11-17. doi:10.1016/S09255214(99)00034-4.

Martin, T.J., Juniper, B.E. 1970. The Cuticles of Plant. Edward Arnold Ltd., London.

Matiacevich, S., Celis Cofré, D., Silva, P., Enrione, J., Osorio, F. 2013. Quality parameters of six cultivars of blueberry using computer vision [online]. Int. J. Food Sci. 2013: 8 pages. doi:10.1155/2013/419535.

Montefiori, M., McGhie, T.K., Hallett, I.C., Costa, G. 2009. Changes in pigments and plastid ultrastructure during ripening of green-fleshed and yellow-fleshed kiwifruit. Sci. Hortic. 119(4): 377-387. doi:10.1016/j.scienta.2008.08.022.

Müller, D., Schantz, M., Richling, E. 2012. High performance liquid chromatography analysis of anthocyanins in bilberries (Vaccinium myrtillus L.), blueberries (Vaccinium corymbosum L.), and corresponding juices. J. Food Sci. 77(4): C340-C345. doi:10.1111/j.1750-3841.2011.02605.x.

Özgen, M., Palta, J.P., Smith, J.D. 2002. Ripeness stage at harvest influences postharvest life of cranberry fruit: physiological and anatomical explanations. Postharvest Biol. Technol. 24(3): 291-299. doi:10.1016/S0925-5214(01)00154-5.

Paniagua, A.C., East, A.R., Hindmarsh, J.P., Heyes, J.A. 2013. Moisture loss is the major cause of firmness change during postharvest storage of blueberry. Postharvest Biol. Technol. 79: 13-19. doi:10.1016/j.postharvbio.2012.12.016. 
Parra, R., Lifante, Z.D., Valdés, B. 2007. Fruit size and picking scar size in some blueberry commercial cultivars and hybrid plants grown in SW Spain. Int. J. Food Sci. Technol. 42(7): 880-886. doi:10.1111/j.1365-2621.2006.01299.x.

Patel, S. 2014. Blueberry as functional food and dietary supplement: The natural way to ensure holistic health. Med. J. Nutrition Metab. 7(2): 133-143. doi:10.13140/2.1.1875.0088.

Peng, Y.B., Zhang, D.P. 2000. Ultrastructure of epidermis and flesh of the developing apple fruit. Acta Phytotaxon. Sin. 42: 794-802.

Perkins-Veazie, P. 2004. Blueberry. In: The commercial storage of fruits, vegetables, and florist and nursery stocks. Edited by K.C. Gross, Wang, C.Y., Saltveit, M. Agricultural Handbook Vol. 66. Betsville, USDA, ARS.

Peschel, S., Beyer, M., Knoche, M. 2003. Surface characteristics of sweet cherry fruit: stomata-number, distribution, functionality and surface wetting. Sci. Hortic. 97: 265278. doi:10.1016/S0304-4238(02)00207-8.

Peschel, S., Franke, R., Schreiber, L., Knoche, M. 2007. Composition of the cuticle of developing sweet cherry fruit. Phytochemistry 68: 1017-1025. doi:10.1016/j.phytochem.2007.01.008.

Pliszka, K. 2002. Borówka amerykańska. Wydawnictwo Działkowiec, Warszawa.

Reynolds, E.S. 1963. The use of lead citrate at high $\mathrm{pH}$ as an electron-opaque stain for electron microscopy. J. Cell Biol. 17: 208-212.

Roy, S., Conway, W.S., Watada, A.E., Sams, C.E., Erbe, E.F., Wergin, W.P. 1999. Changes in the ultrastructure of the epicuticular wax and postharvest calcium uptake in apples. HortSci. 34: 121-124. 
Samuels, L., Kunst, L., Jetter, R. 2008. Scaling plant surfaces: cuticular wax formation by epidermal cells. Ann. Rev. Plant Soil 59: 683-707. doi:10.1146/annurev.arplant.59.103006.093219.

Sapers, G.M., Burgher, A.M., Phillips, J.G., Jones, S.B., Stone, E.G. 1984a. Color and composition of highbush blueberry cultivars. J. Am. Soc. Hortic. Sci. 109: 105-111.

Sapers, G.M., Burgher, A.M., Phillips, J.G., Jones, S.B., Stone, E.G. 1984b. Effects of freezing, thawing and cooking on the appearance of highbush blueberries. J. Am. Soc. Hortic. Sci. 109: 112-117.

Scalzo, J., Stevenson, D., Hedderley, D. 2013. Blueberry estimated harvest from seven new cultivars: Fruit and anthocyanins. Food Chem. 139(1): 44-50. doi:10.1016/j.foodchem.2013.01.091.

Smith, W.W. 1935. The course of stone cell formation in pear fruits. Plant Physiol. 10(4): 587-611. PMCID: PMC439172.

Souza de, V.R., Pereira, P.A.P., da Silva, T.L.T., de Oliveira Lima, L.C., Pio, R., Queiroz, F. 2014. Determination of the bioactive compounds, antioxidant activity and chemical composition of Brazilian blackberry, red raspberry, strawberry, blueberry and sweet cherry fruits. Food Chem. 156: 362-368. doi:10.1016/j.foodchem.2014.01.125.

Spurr, A.R. 1969. A low-viscosity epoxy resin embedding medium for electron microscopy. J. Ultrastruct. Res. 26: 31-43. doi:10.1016/S0022-5320(69)90033-1.

Sterling, C. 1954. Sclereid development and the texture of Bartlett pears. J. Food Sci. 19: 433443. doi:10.1111/j.1365-2621.1954.tb17474.x.

Strik, B.C. 2005. Blueberry - an expanding world berry crop. Chron. Hortic. 45: 7-12.

Strik, B.C., Finn, C.E., Moore, P.P. 2014. Blueberry cultivars for the Pacific Northwest. [Corvallis, Or.]: Oregon State University Extension Service 656: 1-13.

Su, Z. 2012. Anthocyanins and flavonoids of Vaccinium L. Pharm. Crops 3: 7-37. 
Tessmer, M.A., Kluge, R.A., Appezzato-da-Glória, B. 2014. The accumulation of tannins during the development of 'Giombo' and 'Fuyu' persimmon fruits. Sci. Hortic. 172: 292-299. doi:10.1016/j.scienta.2014.04.023.

Tian, L.M., Cao Y.F., Gao Y., Dong X.G. 2011. Effect of stone cells size and flesh texture in pear cultivars. Acta Hortic. Sinica, 38: 1225-1234.

Toivonen, P.M.A., Brummell, D.A. 2008. Biochemical bases of appearance and texture changes in fresh-cut fruit and vegetables. Postharvest Biol. Technol. 48: 1-14. doi:10.1016/j.postharvbio.2007.09.004.

Tsubaki, S., Ozaki, Y., Yonemori, K., Azuma, J.I. 2012. Mechanical properties of fruitcuticular membranes isolated from 27 cultivars of Diospyros kaki Thunb. Food Chem. 132: 2135-2139. doi:10.1016/j.foodchem.2011.12.039.

Vaughan, J.G., Geissler, C.A. 2001. Rośliny jadalne. Prószyński i Spółka, Warszawa.

Vicente, A.R., Ortugno, C., Rosli, H., Powell, A.L.T., Greve, L.C., Labavitch, J.M. 2007. Temporal sequence of cell wall disassembly events in developing fruits. 2. Analysis of blueberry (Vaccinium species). J. Agric. Food Chem. 55: 4125-4130. doi:10.1021/jf063548j.

Wang, H., Wang, W., Li, H., Zhang, P., Zhan, J., Huang, W. 2010. Gene transcript accumulation, tissue and subcellular localization of anthocyanidin synthase (ANS) in developing grape berries. Plant Sci. 179: 103-113. doi:10.1016/j.plantsci.2010.04.002.

Wettstein-Knowles von, P. 1995. Biosynthesis and genetics of waxes. In Waxes: chemistry, molecular biology and functions. Edited by R.J. Hamilton. The Oily Press, Dundee, Scotland. pp. 91-130.

Żurawicz, E. 2003. Pomologia. Państwowe Wydawnictwa Rolnicze i Leśne, Warszawa. 
Table 1. Characteristics of hypantium (stage I), and immature (stage II) and mature (stage III) fruits of 'Bluecrop'. The measurements were made at the equatorial part of the examined organs.

\begin{tabular}{lccc}
\hline Characteristics [in $\mu \mathrm{m}$ ] & Stage I & Stage II & Stage III \\
\hline Thickness of the wax layer $(\mathrm{n}=50)$ & $0.85 \pm 0.24 \mathrm{a}$ & $1.72 \pm 0.32 \mathrm{~b}$ & $2.50 \pm 0.38 \mathrm{c}$ \\
Thickness of the cuticle $(\mathrm{n}=50)$ & $0.60 \pm 0.14 \mathrm{a}$ & $1.62 \pm 0.34 \mathrm{~b}$ & $3.29 \pm 0.64 \mathrm{c}$ \\
Thickness of the outer epidermal cell wall $(\mathrm{n}=50)$ & $1.23 \pm 0.21 \mathrm{a}$ & $3.06 \pm 0.53 \mathrm{~b}$ & $3.81 \pm 0.50 \mathrm{c}$ \\
Height of the epidermal cell $(\mathrm{n}=50)$ & $16.75 \pm 0.62 \mathrm{a}$ & $23.99 \pm 1.59 \mathrm{~b}$ & $22.10 \pm 2.82 \mathrm{c}$ \\
Width of the epidermal cell $(\mathrm{n}=50)$ & $9.58 \pm 1.92 \mathrm{a}$ & $24.11 \pm 2.68 \mathrm{~b}$ & $30.10 \pm 8.08 \mathrm{c}$ \\
Thickness of the hypodermis layer ( $\mathrm{n}=50)$ & $36.22 \pm 2.79 \mathrm{a}$ & $49.10 \pm 6.14 \mathrm{~b}$ & $56.53 \pm 11.36 \mathrm{c}$ \\
Thickness of the hypodermal cell wall $(\mathrm{n}=50)$ & $1.50 \pm 0.34 \mathrm{a}$ & $4.34 \pm 0.54 \mathrm{~b}$ & $4.45 \pm 0.41 \mathrm{~b}$ \\
Total thickness of skin ( $\mathrm{n}=50)$ & $56.67 \pm 4.56 \mathrm{a}$ & $73.45 \pm 7.11 \mathrm{~b}$ & $78.20 \pm 7.49 \mathrm{~b}$ \\
Length of the hypodermal plastids ( $\mathrm{n}=50)$ & $5.03 \pm 0.68 \mathrm{a}$ & $5.39 \pm 0.73 \mathrm{~b}$ & $3.84 \pm 0.57 \mathrm{c}$ \\
Thickness of the stone cell wall $(\mathrm{n}=50)$ & - & $8.80 \pm 1.32 \mathrm{a}$ & $8.92 \pm 1.73 \mathrm{a}$ \\
Height of the stone cell $(\mathrm{n}=50)$ & - & $82.24 \pm 20.67 \mathrm{a}$ & $83.35 \pm 21.68 \mathrm{a}$ \\
Number of the stone cells in mm ${ }^{2}$ cross section $(\mathrm{n}=50)$ & - & $3.59 \pm 1.28 \mathrm{a}$ & $3.65 \pm 1.42 \mathrm{a}$ \\
Width of the hypanthium/unripe fruit/ripe fruit $(\mathrm{n}=20)$ & $2626 \pm 340.50 \mathrm{a}$ & $9700 \pm 850.40 \mathrm{~b}$ & $17850 \pm 1250.50 \mathrm{c}$ \\
Height of the hypanthium/unripe fruit/ripe fruit $(\mathrm{n}=20)$ & $1570 \pm 250.50 \mathrm{a}$ & $5750 \pm 540.50 \mathrm{~b}$ & $12200 \pm 1050.50 \mathrm{c}$ \\
Diameter of the picking scar $(\mathrm{n}=20)$ & - & $1858 \pm 310.50 \mathrm{a}$ & $2430 \pm 480.00 \mathrm{~b}$ \\
\hline
\end{tabular}

Note: Different letters within a line mean statistically significant differences $(\alpha=0.05)$. 


\section{I declare that all figures in this manuscript are the original creations based on the contents of the submitted manuscript.}

Fig. 1. Anthesis stage. $(a, b)$ SLM; Hypanthium (stars) of a 'Bluecrop' flower; lateral (a) and bottom (b) view. (c-h) SEM; Hypanthium surface. (c-e) Note stomata (arrowheads) located mainly on the sepals. $(f-h)$ Rods and rodlets of crystalline wax and areas without wax covered by a smooth cuticle (stars). $(i, j)$ TEM; Outer cell of the hypanthium epidermis with layer of crystalline wax and amorphous cuticle. $\mathrm{c}=$ corolla, $\mathrm{s}=$ sepals, $\mathrm{h}=$ hypantium, ew $=$ epicuticular wax, $\mathrm{cu}=$ cuticle, $\mathrm{cw}=$ cell wall, $\mathrm{v}=$ vacuoles. Scale bars $=3 \mathrm{~mm}(a, b), 50 \mu \mathrm{m}$ $(c, d, f), 10 \mu \mathrm{m}(g), 3 \mu \mathrm{m}(e, h, i), 1 \mu \mathrm{m}(j)$.

Fig. 2. Anthesis stage. ( $a, b)$ LM; Fragments of cross sections of the 'Bluecrop' hypanthium with visible globular tannin deposits in the vacuoles (arrowheads) and plastids with dark granularities (arrows) $(b) .(c, d)$ TEM; $(c)$ Plastids (arrows) in hypodermis cells. $(d)$ Globular, electron-dense tannin deposits in the vacuole of a hypodermis cell. $\mathrm{e}=$ epidermis, $\mathrm{h}$ $=$ hypodermis, $\mathrm{p}=$ parenchyma, $\mathrm{vb}=$ vascular bundles, $\mathrm{n}=$ nucleus, $\mathrm{v}=$ vacuoles. Scale bars $=50 \mu \mathrm{m}(a), 20 \mu \mathrm{m}(b), 5 \mu \mathrm{m}(c, d)$.

Fig. 3. Fruit set stage. $(a, b)$ SLM. Surface of an unripe, green 'Bluecrop' fruit covered by grey wax coating $(a)$ with a visible picking scar $(b) .(c, d)$ SEM; Crystalline wax in the form of densely arranged rods and rodlets $(c)$ and amorphous wax produced by fused crystals (d). (e-h) TEM; (e) Fragment of a section across an epidermis cell in a fruit set with a visible layer of epicuticular wax (stars), the cuticle, and electron-dense oval inclusions in the outer cell wall (rectangles). $(f)$ Outer wall of the epidermis with a visible layer of epicuticular wax (stars) and a cuticle composed of a darker cuticular layer and a lighter cuticle proper layer, with oval inclusions in the cell wall (arrows) and dark granularities in the wax layer (rectangle). (g), Electron-dense granularities in the epicuticular wax layer. $(h)$ Fragment of the outer wall of the epidermis with dark inclusions (arrows) near the cuticular layer. (i) 
Numerous inclusions (arrows) visible in the outer wall of the epidermis. ps $=$ picking scar, ew $=$ epicuticular wax, $\mathrm{cu}=$ cuticle, $\mathrm{cl}=$ cuticle layer, $\mathrm{cp}=$ cuticle proper, $\mathrm{cw}=$ cell wall, $\mathrm{c}=$ cytoplasm, $\mathrm{v}=$ vacuole. Scale bars $=3 \mathrm{~mm}(a, b), 10 \mu \mathrm{m}(c-e), 1 \mu \mathrm{m}(f-h), 500 \mathrm{~nm}(g)$.

Fig. 4. Fruit set stage. $(a-c)$, LM; Fragments of cross sections through the peripheral layers of the pericarp of the 'Bluecrop' stage II fruits with visible stone cells $(a)$ and dark brown tannin deposits (arrowheads) (c). (d-j) TEM; $(d)$ Chloroplasts in the hypodermis cells (arrowheads). (e-g) Oval plastids with numerous electron-transparent inclusions. (h) Elongated plastid with numerous granular inclusions surrounding its envelope. $\mathrm{e}=$ epidermis, $\mathrm{h}=$ hypodermis, $\mathrm{p}=$ parenchyma, $\mathrm{s}=$ stone cells, $\mathrm{cw}=$ cell wall, $\mathrm{v}=$ vacuoles, $\mathrm{p}=$ plastid, $\mathrm{c}=$ cytoplasm. Scale bars $=200 \mu \mathrm{m}(a), 50 \mu \mathrm{m}(b, c), 5 \mu \mathrm{m}(d, e), 1 \mu \mathrm{m}(f-h)$.

Fig. 5. Mature fruit stage. (a, b) SEM; $(a)$, Areas covered by amorphous wax (black stars) formed through fusion of rods and rodlets interspersed by bands with visible, partially transformed crystalline wax structures (white stars). (b), Increased, partially degraded crystalline wax structures from phot. $a$. $(c, d)$ TEM; Outer wall of the epidermis with a visible epicuticular wax layer and a cuticle composed of a darker cuticular layer and a lighter cuticle proper layer. $(e, f) \mathrm{LM}$; Fragments of cross sections through the skin of ripe fruits with a visible epicuticular wax layer (arrowheads), cuticle, and granularities in cell vacuoles. Note detachment of the skin from the fruit flesh (stars) $(e)$. ew $=$ epicuticular wax, $\mathrm{cu}=$ cuticle, $\mathrm{cp}$ $=$ cuticle proper, $\mathrm{cl}=$ cuticular layer, $\mathrm{e}=$ epidermis, $\mathrm{h}=$ hypodermis, $\mathrm{p}=$ parenchyma Scale bars $=10 \mu \mathrm{m}(a), 3 \mu \mathrm{m}(b, c), 500 \mathrm{~nm}(d), 50 \mu \mathrm{m}(e), 20 \mu \mathrm{m}(f)$.

Fig. 6. Mature fruit stage. (a-e) TEM; Different plastid forms in hypodermal cells. ( $a$ c) degenerated chloroplasts with plastoglobules (arrowheads) and a distorted structure of the internal membrane. (d-f) plastids with a degenerated system of internal membranes with electron-dense, different size, and irregular shape inclusions visible both inside and outside the plastid envelope. Scale bars $=5 \mu \mathrm{m}(a), 2 \mu \mathrm{m}(b-e), 300 \mathrm{~nm}(f)$. 

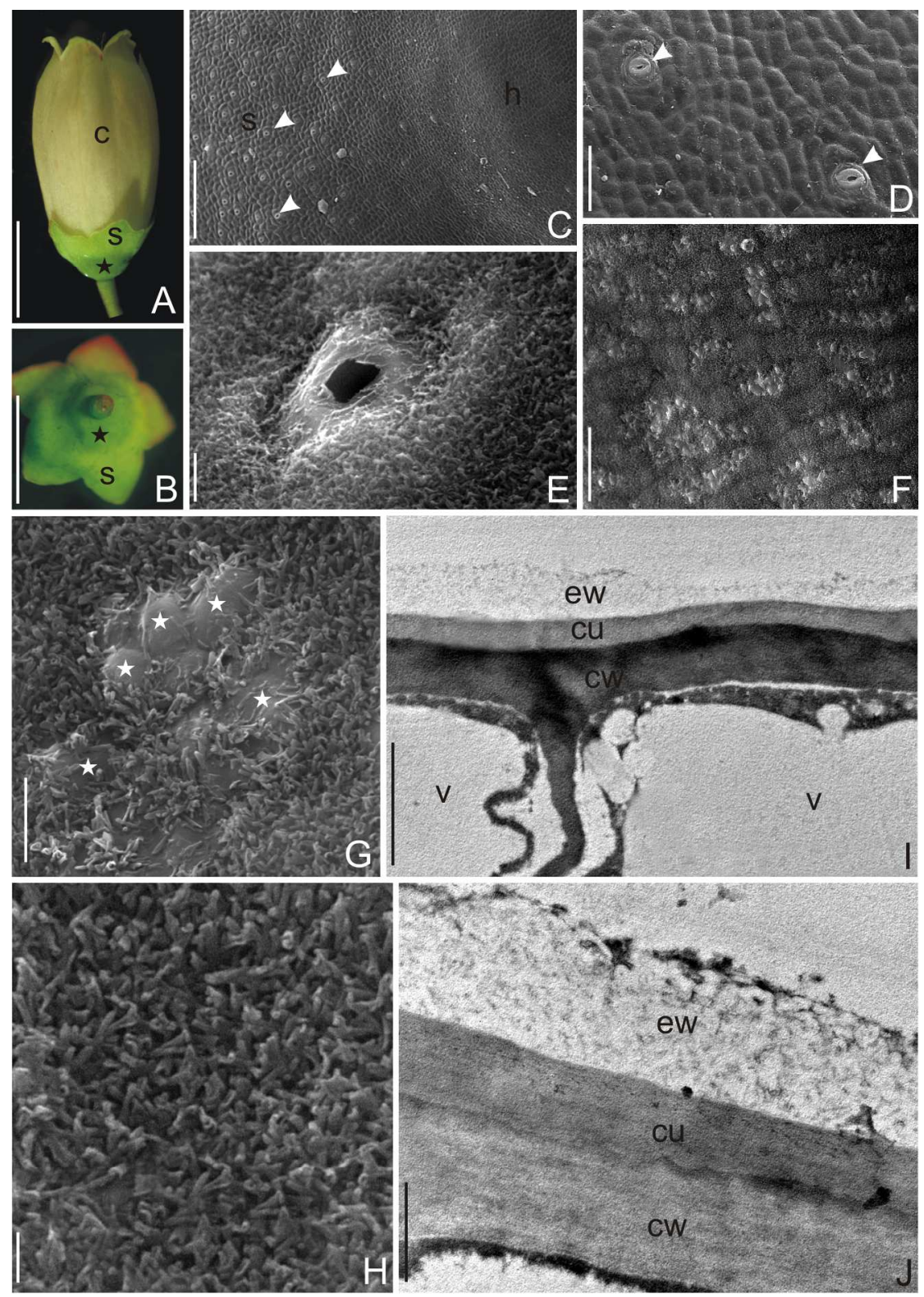

Fig. 1. Anthesis stage. (a, b) SLM; Hypanthium (stars) of a 'Bluecrop' flower; lateral (a) and bottom (b) view. (c-h) SEM; Hypanthium surface. (c-e) Note stomata (arrowheads) located mainly on the sepals. (f-h) Rods and rodlets of crystalline wax and areas without wax covered by a smooth cuticle (stars). ( $i, j$ ) TEM; Outer cell of the hypanthium epidermis with layer of crystalline wax and amorphous cuticle. $c=$ corolla, $s=$ sepals, $\mathrm{h}=$ hypantium, ew $=$ epicuticular wax, $\mathrm{cu}=$ cuticle, $\mathrm{cw}=$ cell wall, $\mathrm{v}=$ vacuoles. Scale bars $=3 \mathrm{~mm}$ $(a, b), 50 \mu \mathrm{m}(c, d, f), 10 \mu \mathrm{m}(\mathrm{g}), 3 \mu \mathrm{m}(e, h, i), 1 \mu \mathrm{m}(\mathrm{j})$. $156 \times 221 \mathrm{~mm}(300 \times 300 \mathrm{DPI})$ 


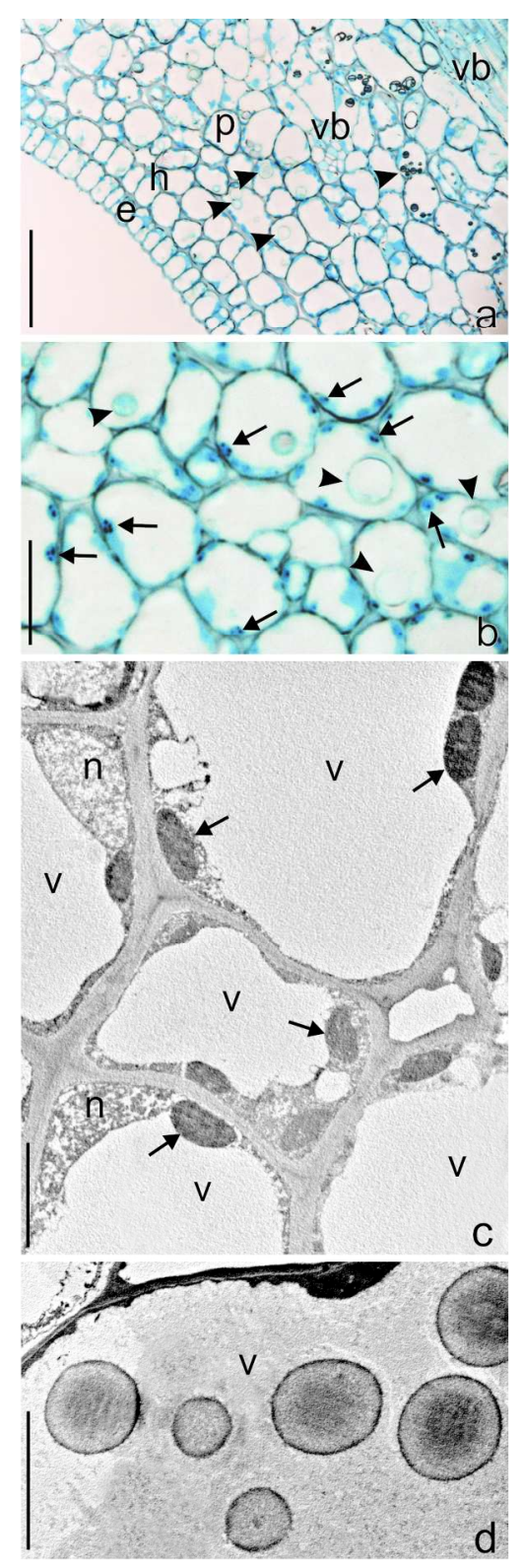

Fig. 2. Anthesis stage. (a, b) LM; Fragments of cross sections of the 'Bluecrop' hypanthium with visible globular tannin deposits in the vacuoles (arrowheads) and plastids with dark granularities (arrows) (b). (c, d) TEM; (c) Plastids (arrows) in hypodermis cells. (d) Globular, electron-dense tannin deposits in the vacuole of a hypodermis cell. $\mathrm{e}=$ epidermis, $\mathrm{h}=$ hypodermis, $\mathrm{p}=$ parenchyma, $\mathrm{vb}=$ vascular bundles, $\mathrm{n}=$ nucleus,

$v=$ vacuoles. Scale bars $=50 \mu \mathrm{m}(\mathrm{a}), 20 \mu \mathrm{m}(\mathrm{b}), 5 \mu \mathrm{m}(\mathrm{c}, \mathrm{d})$. $71 \times 223 \mathrm{~mm}(300 \times 300$ DPI $)$ 


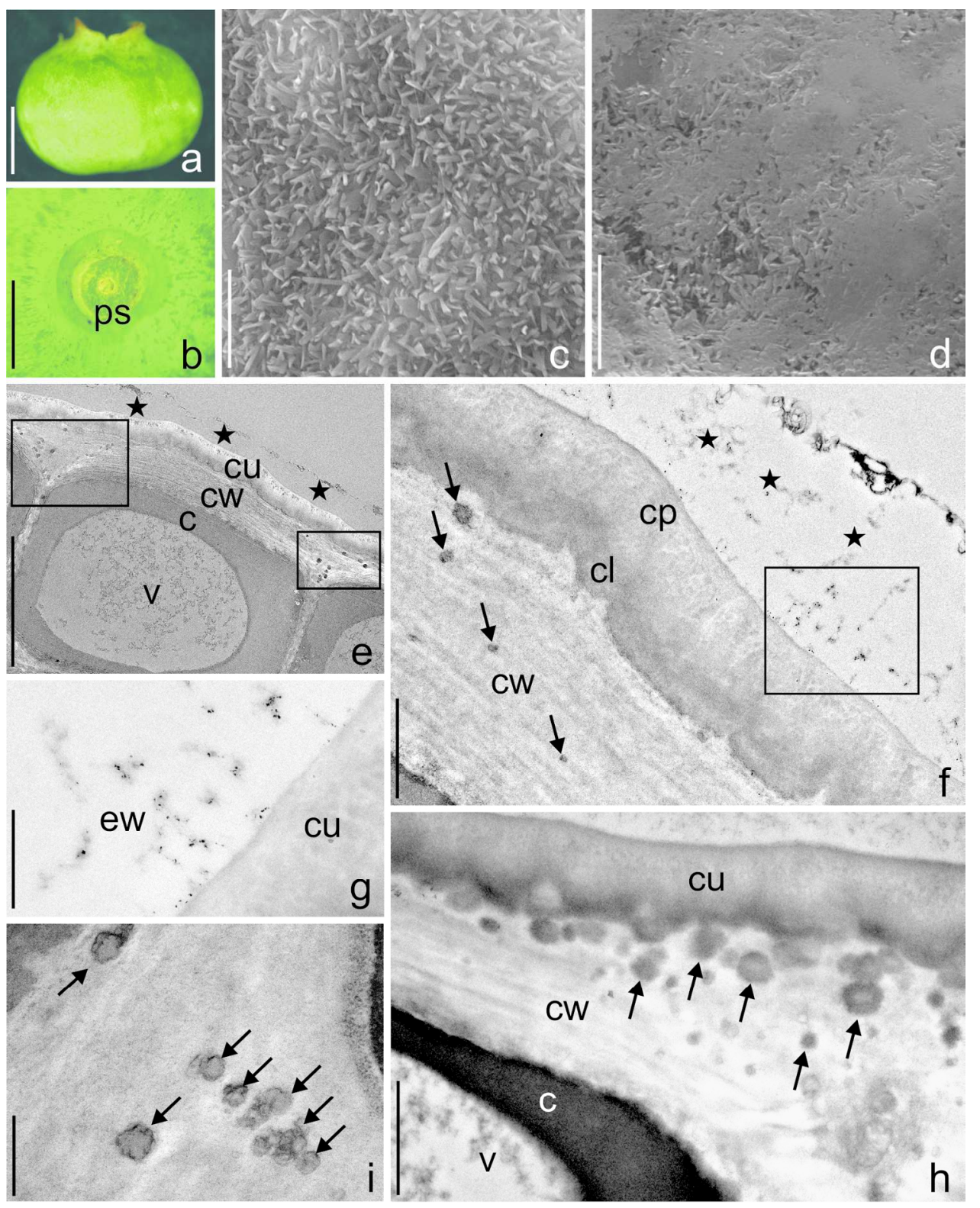

Fig. 3. Fruit set stage. (a, b) SLM. Surface of an unripe, green 'Bluecrop' fruit covered by grey wax coating

(a) with a visible picking scar (b). (c, d) SEM; Crystalline wax in the form of densely arranged rods and rodlets (c) and amorphous wax produced by fused crystals (d). (e-h) TEM; (e) Fragment of a section across an epidermis cell in a fruit set with a visible layer of epicuticular wax (stars), the cuticle, and electron-dense oval inclusions in the outer cell wall (rectangles). (f) Outer wall of the epidermis with a visible layer of epicuticular wax (stars) and a cuticle composed of a darker cuticular layer and a lighter cuticle proper layer, with oval inclusions in the cell wall (arrows) and dark granularities in the wax layer (rectangle). (g), Electron-dense granularities in the epicuticular wax layer. (h) Fragment of the outer wall of the epidermis with dark inclusions (arrows) near the cuticular layer. (i) Numerous inclusions (arrows) visible in the outer wall of the epidermis. ps = picking scar, ew = epicuticular wax, $\mathrm{cu}=$ cuticle, $\mathrm{cl}=$ cuticle layer, $\mathrm{cp}=$ cuticle proper, $c w=$ cell wall, $c=$ cytoplasm, $v=$ vacuole. Scale bars $=3 \mathrm{~mm}(\mathrm{a}, \mathrm{b}), 10 \mu \mathrm{m}(\mathrm{c}-\mathrm{e}), 1 \mu \mathrm{m}(\mathrm{f}-\mathrm{h}), 500$ $\mathrm{nm}(\mathrm{g})$.

$147 \times 183 \mathrm{~mm}(300 \times 300 \mathrm{DPI})$ 


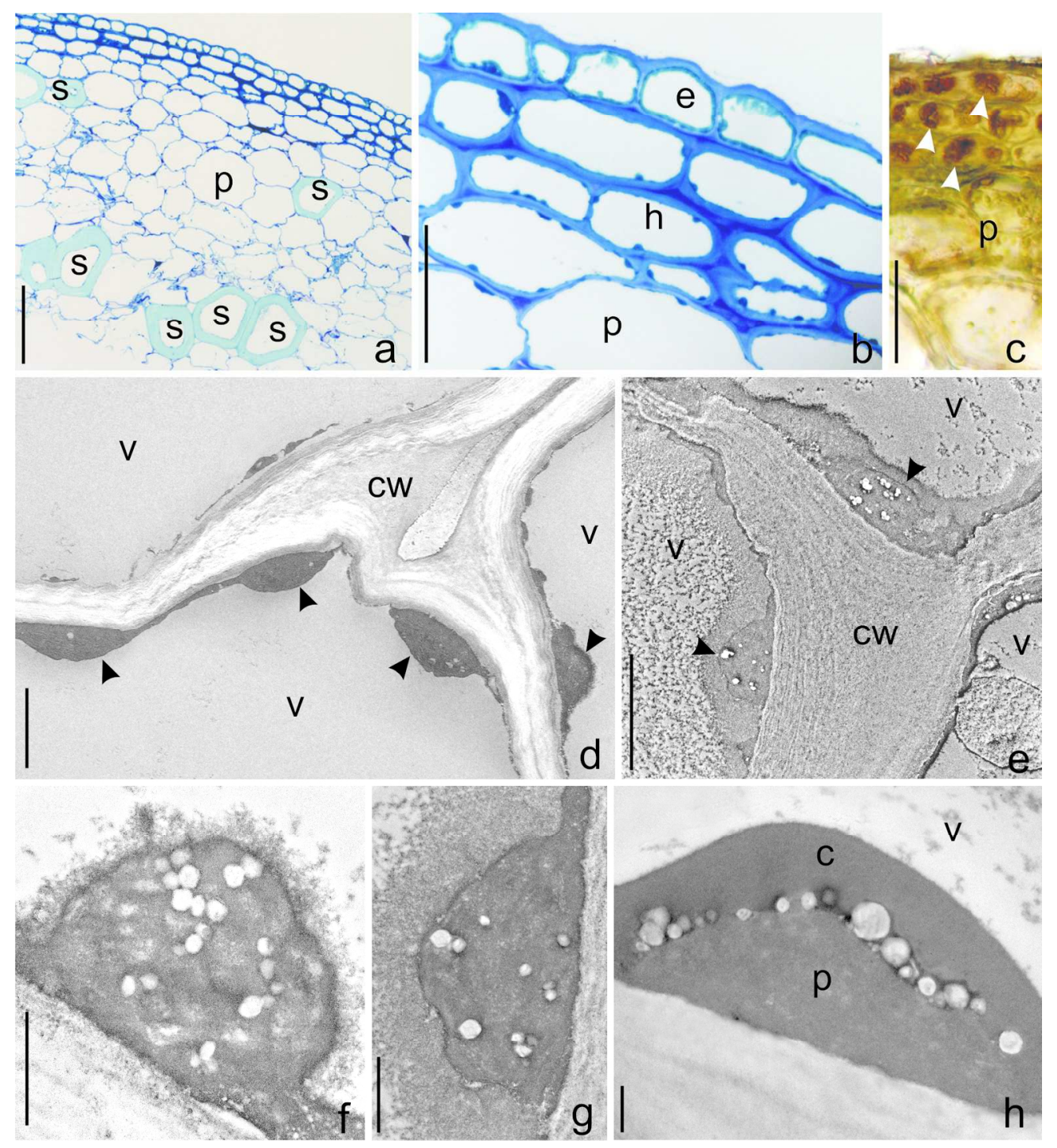

Fig. 4. Fruit set stage. (a-c), LM; Fragments of cross sections through the peripheral layers of the pericarp of the 'Bluecrop' stage II fruits with visible stone cells (a) and dark brown tannin deposits (arrowheads) (c). (dj) TEM; (d) Chloroplasts in the hypodermis cells (arrowheads). (e-g) Oval plastids with numerous electrontransparent inclusions. (h) Elongated plastid with numerous granular inclusions surrounding its envelope. e $=$ epidermis, $\mathrm{h}=$ hypodermis, $\mathrm{p}=$ parenchyma, $\mathrm{s}=$ stone cells, $\mathrm{cw}=$ cell wall, $\mathrm{v}=$ vacuoles, $\mathrm{p}=$ plastid, $\mathrm{c}$ $=$ cytoplasm. Scale bars $=200 \mu \mathrm{m}(\mathrm{a}), 50 \mu \mathrm{m}(\mathrm{b}, \mathrm{c}), 5 \mu \mathrm{m}(\mathrm{d}, \mathrm{e}), 1 \mu \mathrm{m}(\mathrm{f}-\mathrm{h})$.

$$
154 \times 169 \mathrm{~mm} \text { (300 x } 300 \text { DPI) }
$$




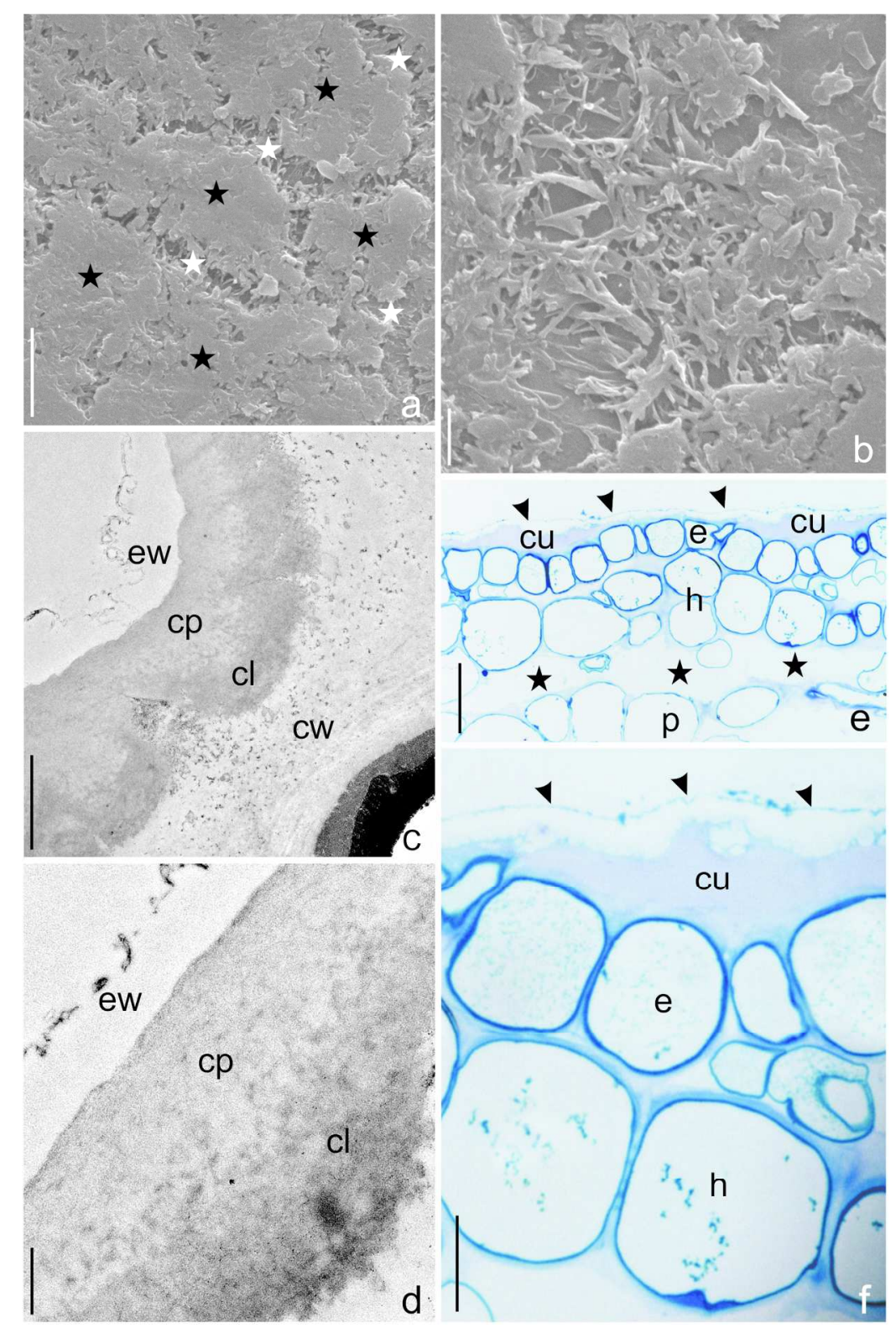

Fig. 5. Mature fruit stage. (a, b) SEM; (a), Areas covered by amorphous wax (black stars) formed through fusion of rods and rodlets interspersed by bands with visible, partially transformed crystalline wax structures (white stars). (b), Increased, partially degraded crystalline wax structures from phot. a. (c, d) TEM; Outer wall of the epidermis with a visible epicuticular wax layer and a cuticle composed of a darker cuticular layer and a lighter cuticle proper layer. (e, f) LM; Fragments of cross sections through the skin of ripe fruits with a visible epicuticular wax layer (arrowheads), cuticle, and granularities in cell vacuoles. Note detachment of

the skin from the fruit flesh (stars) (e). ew = epicuticular wax, $\mathrm{cu}=$ cuticle, $\mathrm{cp}=\mathrm{cuticle}$ proper, $\mathrm{cl}=$ cuticular layer, $\mathrm{e}=$ epidermis, $\mathrm{h}=$ hypodermis, $\mathrm{p}=$ parenchyma. Scale bars $=10 \mu \mathrm{m}(\mathrm{a}), 3 \mu \mathrm{m}(\mathrm{b}, \mathrm{c}), 500$ $\mathrm{nm}(\mathrm{d}), 50 \mu \mathrm{m}(\mathrm{e}), 20 \mu \mathrm{m}(\mathrm{f})$. $140 \times 212 \mathrm{~mm}(300 \times 300 \mathrm{DPI})$ 


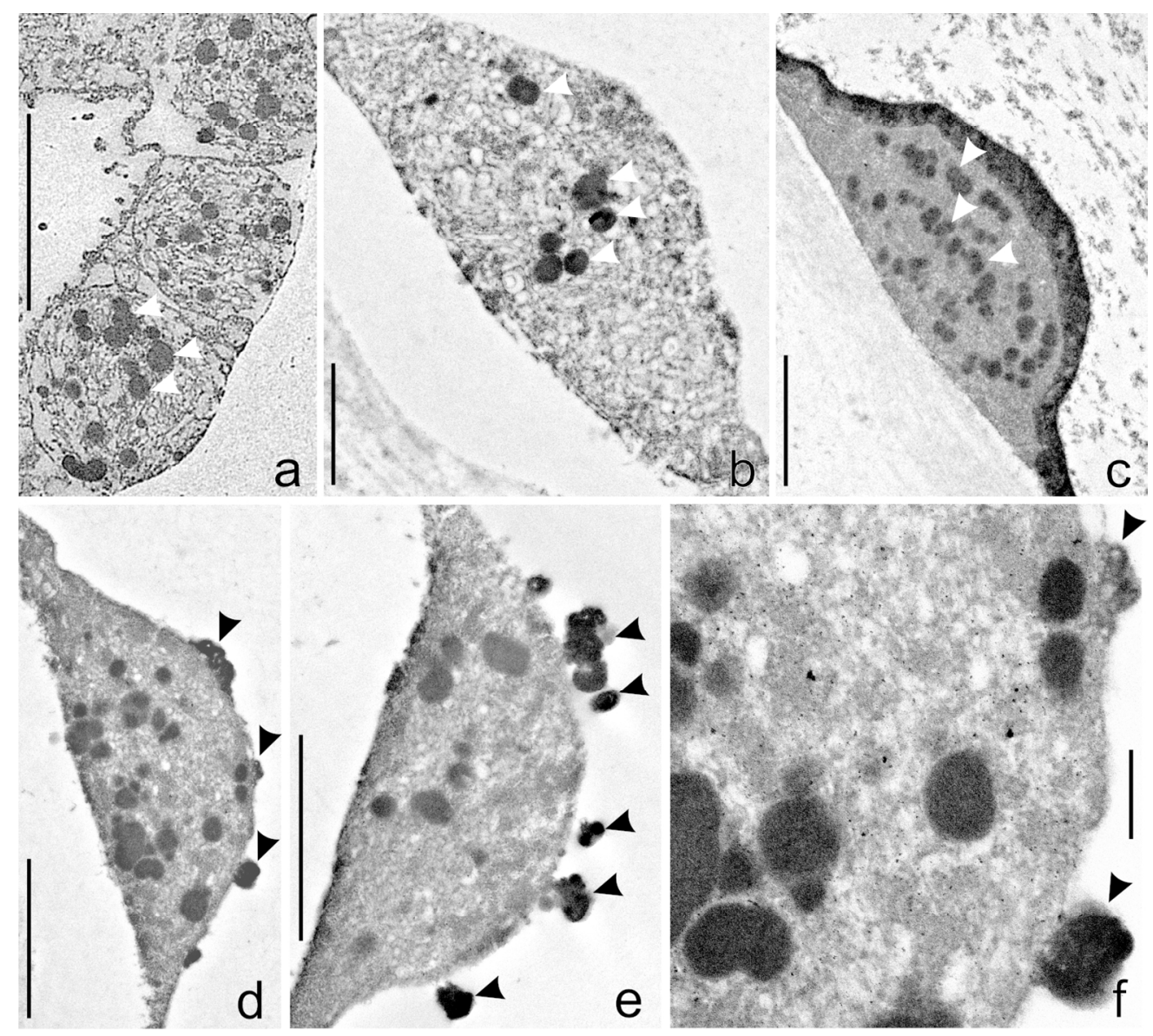

Fig. 6. Mature fruit stage. (a-e) TEM; Different plastid forms in hypodermal cells. (a-c) degenerated chloroplasts with plastoglobules (arrowheads) and a distorted structure of the internal membrane. (d-f) plastids with a degenerated system of internal membranes with electron-dense, different size, and irregular shape inclusions visible both inside and outside the plastid envelope. Scale bars $=5 \mu \mathrm{m}(\mathrm{a}), 2 \mu \mathrm{m}(\mathrm{b}-\mathrm{e})$, $300 \mathrm{~nm}(\mathrm{f})$.

$136 \times 122 \mathrm{~mm}(300 \times 300$ DPI $)$ 